\title{
Usage of environmental isotopes in characterizing groundwater recharge sources
}

\author{
H. Bhandary, K. Al-Fahad, M. Al-Senafy \& A. Al-Khalid \\ Hydrology Department, Water Resources Division, \\ Kuwait Institute for Scientific Research, Kuwait
}

\begin{abstract}
Rising groundwater has affected many urban areas in the Middle East from large cities to individual development sites, resulting in widespread and costly damage to property, and dangers to public health. The main objective of this study is to use the environmental isotopes to identify the recharge source that is causing groundwater rise. The study area is located within the Greater Burgan oil field of Kuwait and covers an area of $25 \mathrm{~km}^{2}$. The stable isotopes oxygen-18 $\left({ }^{18} \mathrm{O}\right)$ and deuterium $\left({ }^{2} \mathrm{H}\right)$ were used to investigate the origin of water in the aquifer system while the radioactive isotopes carbon-14 $\left({ }^{14} \mathrm{C}\right)$ and tritium $\left({ }^{3} \mathrm{H}\right)$, were used to estimate the age and circulation of groundwater. The results of ${ }^{14} \mathrm{C}$ and tritium analyses have indicated that the sampled groundwater had experienced limited recharge from recent rainfall events. The isotopic fingerprints of potential recharge sources were markedly different from those of the groundwater, indicating no recharge from these sources. The isotopic similarity between the two aquifers confirmed the hydraulic interconnection between Dammam aquifer and the overlying Kuwait Group aquifer. It was concluded that the rise of the groundwater in the vicinity of the study area can be attributed to the upward seepage from Dammam Formation water to the subsurface and the infiltration of rainfall and water from the overflow of the nearby disposal pit.

Keywords: tritium, oxygen-18, deuterium, carbon-14, aquifer, meteoric water line, rain water, isotopic finger prints, depleted, enriched.
\end{abstract}

\section{Introduction}

A rise in the shallow unconfined groundwater level at the Booster Station 140 (BS-140) in the Burgan oil field of the Kuwait Oil Company (KOC), bringing 
the water table within $2 \mathrm{~m}$ of the ground surface, is causing water logging of the underground facilities in the station. The study area site covers an area of $25 \mathrm{~km}^{2}$ within the Greater Burgan oil field with the BS-140 located at the center. The upper geological formations up to about $1200 \mathrm{~m}$ composed of the two main groundwater aquifers, i.e., Kuwait Group and Dammam Formation. The study area contains about 135 oil production wells and two abandoned quarries which were previously used as landfills and are having free water presently at the bottom.

The environmental isotopes i.e., hydrogen $(\mathrm{H})$, carbon $(\mathrm{C})$, nitrogen $(\mathrm{N})$, oxygen $(\mathrm{O})$ and sulfide $(\mathrm{S})$ are naturally occurring isotopes of elements found in abundance in the environment. These are the principal elements of hydrological, geological and biological systems. They are used to trace not only groundwater provenance, but also recharge processes, subsurface processes, geochemical reactions and reaction rates (Clark and Fritz [1]). The stable isotopes oxygen-18 $\left({ }^{18} \mathrm{O}\right)$ and deuterium $\left({ }^{2} \mathrm{H}\right)$ were used in different hydrological study to investigate the origin of water in the aquifer system in the study area. The radioactive isotopes, such as carbon-14 $\left({ }^{14} \mathrm{C}\right)$ and tritium $\left({ }^{3} \mathrm{H}\right)$, are used to estimate the age and circulation of groundwater. The environmental isotopes were utilized in this study to characterize the groundwater system in the area of the Booster Station140 , to determine its age and to estimate the time and sources of recharge water to the aquifer system causing the water table rise.

\section{Groundwater sampling}

Groundwater samples were collected from a total of 14 wells in the study area. All wells were completed in the Kuwait group except one well in the lower Dammam formation. Additionally, samples were collected from freshwater network, fire station water, wastewater network, recreation lake in the area and from abandoned query. Groundwater samples were collected using electric submersible pumps and a flow cell was used to record the stabilization of the field parameters. Groundwater samples were collected for isotopic analysis following procedures described by International Atomic Energy Agency (IAEA) isotopes sampling protocol.

\section{Laboratory analysis}

Groundwater samples were analyzed for oxygen-18 $\left({ }^{18} \mathrm{O}\right)$, deuterium $\left({ }^{2} \mathrm{H}\right)$, carbon-14 $\left({ }^{14} \mathrm{C}\right)$ and tritium $\left({ }^{3} \mathrm{H}\right)$ isotopes.

The laboratory analyses of the collected samples which were carried out at the International Atomic Energy Agency (IAEA) laboratory in Tunisia are presented in Table 1. Table 2 presents the analyses of stable isotopes ${ }^{18} \mathrm{O}$ and ${ }^{2} \mathrm{H}$ carried out in the hydrology laboratory in Kuwait Institute for Scientific Research (KISR). An off-axis integrated cavity output spectroscopy (OA-ICOS) water isotope analyzer (Los Gatos model 908-0008) was used to analyze Oxygen 18 and Deuterium in water samples. 
Table 1: Isotopic analysis and age determination by IAEA laboratory in Tunisia.

\begin{tabular}{|l|c|c|c|c|c|c|}
\hline Sample & ${ }^{3} \mathrm{H}$ & ${ }^{3} \mathrm{H} \_$ERR & ${ }^{14} \mathrm{C}$ & ${ }^{14}$ C_ERR & Apparent Age & Age_ \\
\hline BS-6 & 0.95 & 0.3 & 40 & 1.4 & 7500 & 330 \\
\hline BS-9 & 0.36 & 0.2 & 36 & 0.8 & 7900 & 190 \\
\hline BS-10 & 0.53 & 0.2 & 45 & 1.5 & 6400 & 320 \\
\hline BS-14 & 0.09 & 0.3 & 10.5 & 1 & 18200 & 800 \\
\hline
\end{tabular}

Table 2: $\quad$ Results of stable isotope analysis at hydrology laboratory in KISR.

\begin{tabular}{|c|c|c|}
\hline Sample No. & Deuterium (\%o) & Oxygen-18 (\%o) \\
\hline BS-01 & -11.63 & -1.33 \\
\hline BS-02 & -7.16 & -0.17 \\
\hline BS-03 & 1.96 & 0.20 \\
\hline BS-04 & -5.69 & 0.29 \\
\hline BS-05 & 4.24 & 2.56 \\
\hline BS-06 & -13.00 & -0.42 \\
\hline BS-07 & -9.81 & 0.04 \\
\hline BS-08 & -10.96 & 0.02 \\
\hline BS-09 & -9.86 & 0.11 \\
\hline BS-10 & -7.98 & 0.37 \\
\hline BS-11 & -9.02 & -0.17 \\
\hline BS-12 & -13.61 & -0.69 \\
\hline BS-13 & -8.53 & -0.08 \\
\hline BS-14 & -20.63 & -1.49 \\
\hline $\mathrm{FS}^{1}$ & -6.85 & 1.76 \\
\hline $\mathrm{WW}^{1}$ & -12.93 & -4.29 \\
\hline $\mathrm{QU}^{1}$ & 13.83 & 4.39 \\
\hline $\mathrm{FR}^{1}$ & -10.62 & -1.49 \\
\hline $\mathrm{RL}^{1}$ & 25.98 & 6.84 \\
\hline
\end{tabular}

${ }^{\mathrm{I}}$ FS - Fire Service Network; WW - Wastewater Network; QU - Abandoned Quarry; FR - Freshwater Network; RL - Recreational Lake

\section{Results and discussion}

\subsection{Radiocarbon}

Carbon-14 is a radioactive isotope of carbon and is expressed in terms of percent modern carbon $(\mathrm{pmc})$. It emits $\beta$-radiation with a maximum energy of 156 
million electron volt $(\mathrm{MeV})$ and has half-life of 5,730 years (Craig [2]). The carbon-14 $\left({ }^{14} \mathrm{C}\right)$ results clearly indicated water of two different ages. The calculated apparent groundwater ages ranged between 6400 and $7900 \mathrm{yr}$ for the Kuwait Group and 18200 years for the Dammam Formation which clearly distinguished water from the two aquifers.

\subsection{Tritium}

Tritium is a radioactive isotope of hydrogen having mass of -3 , half life of 12.26 years and $\beta$ - (radiation of maximum energy) of $18.1 \mathrm{MeV}$ (Craig [2]). The analyzed samples contained detectable tritium in low concentrations $(<1 \mathrm{TU})$. The tritium values for Kuwait group water ranged between 0.36 and 0.95 TU. The tritium concentration in Dammam Formation water is 0.09 TU. The existence of traces of tritium in Kuwait Group water indicates a limited recent recharge and Dammam formation has no recent recharge.

\subsection{Stable isotopes}

The isotopic composition of oxygen-18 and deuterium are expressed as per mil deviation $\left(\delta \%\right.$ ) of the ratio ${ }^{18} \mathrm{O} /{ }^{16} \mathrm{O}$ or ${ }^{2} \mathrm{H} /{ }^{1} \mathrm{H}$ against VSMOW (Vienna Standard Mean Ocean Water). The stable isotopic analysis of the groundwater samples and expected source water samples of the study area are presented in Table 2. The plot of $\delta \mathrm{D}$ and $\delta 180$ values of the groundwater samples bailed and pumped, Dammam aquifer water, recreation lake water, quarry water, fire station water, wastewater, freshwater are shown in Fig.1 with respect to global meteoric water line $(\mathrm{GMWL})(\delta 2 \mathrm{H}=8 \delta 18 \mathrm{O}+10$; Craig, 1981), United Arab Emirates (UAE) local meteoric water line $(\delta 2 \mathrm{H}=8 \delta 18 \mathrm{O}+17$ (Zouari [3]) and North Oman meteoric water line $(\delta 2 \mathrm{H}=8 \delta 18 \mathrm{O}+16$ (Zouari [3])). The UAE and North Oman lines were used as the closest local meteoric lines available. The

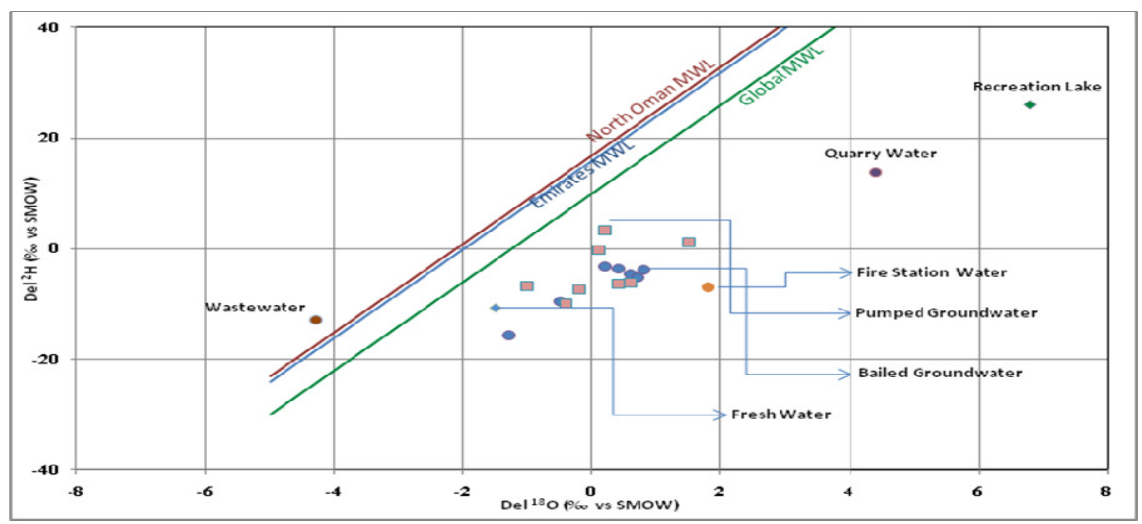

Figure 1: Cross-plot of $\delta^{2} \mathrm{H}$ versus $\delta^{18} \mathrm{O}$ for water samples from the study area. 
groundwater points fall on a line below that of the GMWL, indicating the effect of evaporation. The pumped groundwater values for $\delta 18 \mathrm{O}$ varied from $-0.77 \%$ to $0.26 \%$ and for bailed groundwater was $-0.97 \%$ to $3.06 \%$ showing the evaporated rainwater recharge in the area. The pumped groundwater values for $\delta 2 \mathrm{H}$ varied from $-13.83 \%$ to $-8.04 \%$ and for bailed groundwater was $-9.82 \%$ o to $7.37 \%$ showing evaporated rainwater recharge in the top part of the Kuwait group aquifer. The $\delta 18 \mathrm{O}$ and $\delta 2 \mathrm{H}$ values for Dammam aquifer water was $0.51 \%$ and $-10.37 \%$ o respectively indicating no recent infiltration water reaching Dammam aquifer. This isotopic similarity between the two aquifers confirmed the hydraulic interconnection between Dammam aquifer and the overlying Kuwait Group aquifer. The effect of evaporation is quite clear in the groundwater because its isotopic composition is slightly enriched with heavy isotopes indicating that, during relatively heavy rainfall, rainwater is collected in the depressions and affected by evaporation which make it enriched in heavy stable isotopes. This water then infiltrates and mixes with the water of the underlying Kuwait group aquifer.

The stable isotopic composition of the water from the recreation lake and the quarry showed heavy enrichment which could clearly be attributed to evaporation. The stable isotopic signatures of brackish, fresh and wastewater from networks did not match with that of groundwater samples showing none of these sources affecting groundwater in the study area. Moreover, enriched deuterium values in the groundwater of well nos. BS-02 and BS-07 showed the presence of another source of water of different quality mixing with groundwater. The source of this water can be attributed to the overflow of the wastewater disposal pit located near these two wells. The water quality results confirm this mixing of groundwater with contaminated water.

Combining the implications from $14 \mathrm{C}$ and tritium results, it can be concluded that the sampled groundwater at the study area had experienced limited recharge from recent rainfall events. The isotope data also demonstrated clear difference in the ages of the water from the Dammam Formation from that in the Kuwait Group, the former being older. Furthermore, the depleted oxygen 18 and deuterium contents in the water of the Dammam Formation compared to that in the Kuwait Group differentiated clearly the two (fig. 1).

\section{Conclusions and recommendations}

The results of ${ }^{14} \mathrm{C}$ and tritium analyses have indicated that the sampled groundwater at the study area had experienced limited recharge from recent rainfall events. The isotopic data also demonstrated clear difference between the ages of the water from the Dammam Formation and that from the Kuwait Group, the former being older. Furthermore, the depleted oxygen 18 and deuterium contents in the water of the Dammam Formation compared to that in the Kuwait Group differentiated clearly the two. The isotopic fingerprints and the quality of the samples collected from the networks and the other potential recharge sources were markedly different from those of the groundwater, indicating no recharge from these expected sources. The isotopic similarity between the two aquifers 
confirmed the hydraulic interconnection between Dammam aquifer and the overlying Kuwait Group aquifer. It was concluded that the rise of the groundwater in the vicinity of the study area can be attributed to the upward seepage from Dammam Formation water to the subsurface and the infiltration of rainfall and water from the overflow of the nearby disposal pit. To deal with the water rise problem, efforts should be exerted to reduce the symptoms of the problem by designing and implementing a dewatering operation that takes into consideration the geo-mechanical properties of the soil and the potential impact of groundwater pumping on the foundations of the buildings within the area.

\section{Acknowledgements}

The authors would like to express his gratitude to the Kuwait Oil Company (KOC) for funding the project and the team members of Research and Technology Group of KOC for assisting in the execution of the project. The constant support and encouragement of Kuwait Institute for Scientific Research (KISR) management is gratefully acknowledged.

\section{References}

[1] Clark, I. and P. Fritz. Environmental Isotopes in Hydrogeology. LLC, New York: CRC Press 328pp. 2000.

[2] Craig, H. Isotopic variations in meteoric waters. Science 133:1702-1703, 1981.

[3] Zouari K. Isotopes hydrology techniques in water resources management. Assessment of Artificial Groundwater Recharge: Tawiyaen and Wurrayah Dams (UAE). IAEA Report, 2004. 